\title{
Front Matter: Volume 7642
}

, "Front Matter: Volume 7642," Proc. SPIE 7642, Electroactive Polymer Actuators and Devices (EAPAD) 2010, 764201 (22 April 2010); doi: 10.1117/12.863316

EDIE Event: SPIE Smart Structures and Materials + Nondestructive Evaluation and SPE. Health Monitoring, 2010, San Diego, California, United States 


\title{
PROCEEDINGS OF SPIE
}

\section{Electroactive Polymer Actuators and Devices (EAPAD) 2010}

\author{
Yoseph Bar-Cohen \\ Editor \\ 8-11 March 2010 \\ San Diego, California, United States \\ Sponsored by \\ SPIE \\ Cosponsored by \\ American Society of Mechanical Engineers (United States) \\ Cooperating Organizations \\ Intelligent Materials Forum (Japan) \\ Jet Propulsion Laboratory (United States) \\ National Science Foundation (United States) \\ Published by \\ SPIE
}

Volume 7642 
The papers included in this volume were part of the technical conference cited on the cover and title page. Papers were selected and subject to review by the editors and conference program committee. Some conference presentations may not be available for publication. The papers published in these proceedings reflect the work and thoughts of the authors and are published herein as submitted. The publisher is not responsible for the validity of the information or for any outcomes resulting from reliance thereon.

Please use the following format to cite material from this book:

Author(s), "Title of Paper," in Electroactive Polymer Actuators and Devices (EAPAD) 2010, edited by Yoseph Bar-Cohen, Proceedings of SPIE Vol. 7642 (SPIE, Bellingham, WA, 2010) Article CID Number.

ISSN 0277-786X

ISBN 9780819480576

Published by

SPIE

P.O. Box 10, Bellingham, Washington 98227-0010 USA

Telephone +1 3606763290 (Pacific Time) · Fax +1 3606471445

SPIE.org

Copyright (c) 2010, Society of Photo-Optical Instrumentation Engineers

Copying of material in this book for internal or personal use, or for the internal or personal use of specific clients, beyond the fair use provisions granted by the U.S. Copyright Law is authorized by SPIE subject to payment of copying fees. The Transactional Reporting Service base fee for this volume is $\$ 18.00$ per article (or portion thereof), which should be paid directly to the Copyright Clearance Center (CCC), 222 Rosewood Drive, Danvers, MA 01923. Payment may also be made electronically through CCC Online at copyright.com. Other copying for republication, resale, advertising or promotion, or any form of systematic or multiple reproduction of any material in this book is prohibited except with permission in writing from the publisher. The CCC fee code is 0277-786X/10/\$18.00.

Printed in the United States of America.

Publication of record for individual papers is online in the SPIE Digital Library.

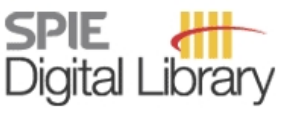

SPIEDigitalLibrary.org

Paper Numbering: Proceedings of SPIE follow an e-First publication model, with papers published first online and then in print and on CD-ROM. Papers are published as they are submitted and meet publication criteria. A unique, consistent, permanent citation identifier (CID) number is assigned to each article at the time of the first publication. Utilization of CIDs allows articles to be fully citable as soon they are published online, and connects the same identifier to all online, print, and electronic versions of the publication. SPIE uses a six-digit CID article numbering system in which:

- The first four digits correspond to the SPIE volume number.

- The last two digits indicate publication order within the volume using a Base 36 numbering system employing both numerals and letters. These two-number sets start with 00, 01, 02, 03, 04 , $05,06,07,08,09,0 A, 0 B \ldots$. OZ, followed by 10-1Z, 20-2Z, etc.

The CID number appears on each page of the manuscript. The complete citation is used on the first page, and an abbreviated version on subsequent pages. Numbers in the index correspond to the last two digits of the six-digit CID number. 


\title{
Contents
}

\author{
xiii Conference Committee \\ xvii Introduction
}

\section{PLENARY SESSION}

764202 Organic bionics (Plenary Paper) [7642-122]

G. G. Wallace, S. E. Moulton, C. Wang, Univ. of Wollongong (Australia)

\section{HAPTIC/TACTILE INTERFACES AND BRAILLE DISPLAYS I}

764206 Refreshable Braille displays using EAP actuators [7642-04]

Y. Bar-Cohen, Jet Propulsion Lab. (United States)

764207 EAP actuators aid the quest for the 'Holy Braille' of tactile displays [7642-05]

N. Runyan, D. Blazie, National Braille Press (United States)

764209 Scavenging energy from human motion with fubular dielectric polymer [7642-111]

C. Jean-Mistral, CEA-LETI-Minatec (France) and TIMA (France); S. Basrour, TIMA (France)

$76420 \mathrm{~A}$ The integration of novel EAP-based Braille cells for use in a refreshable tactile display [7642-07]

N. Di Spigna, P. Chakraborti, D. Winick, P. Yang, T. Ghosh, P. Franzon, North Carolina State Univ. (United States)

$7642 \mathrm{OB}$ The development of compact electroactive polymer actuators suitable for use in full page Braille displays [7642-08]

L. J. Gorny, The Pennsylvania State Univ. (United States); B. C. Zellers, Strategic Polymer Sciences (United States); M. Lin, S. Liu, Q. M. Zhang, The Pennsylvania State Univ. (United States)

\section{HAPTIC/TACTILE INTERFACES AND BRAILLE DISPLAYS II}

7642 OC Bistable electroactive polymers (BSEP): large-strain actuation of rigid polymers (Invited Paper) [7642-09]

Z. Yu, X. Niu, P. Brochu, W. Yuan, H. Li, Univ. of California, Los Angeles (United States); B. Chen, NASA Ames Research Ctr. (United States); Q. Pei, Univ. of California, Los Angeles (United States)

7642 OD Vibrotactile display for mobile applications based on dielectric elastomer stack actuators [7642-10]

M. Matysek, P. Lotz, K. Flittner, H. F. Schlaak, Technische Univ. Darmstadt (Germany) 
7642 OE Hydrostatically coupled dielectric elastomer actuators for tactile displays and cutaneous stimulators [7642-11]

F. Carpi, G. Frediani, D. De Rossi, Univ. of Pisa (Italy)

7642 OF A flexible fingertip tactile sensor [7642-12]

D. S. Kim, N. H. Chuc, S. M. Jin, K. J. An, V. H. Phuc, J. Koo, Y. Lee, J-D. Nam, H. R. Choi, Sungkyunkwan Univ. (Korea, Republic of)

$7642 \mathrm{OH} \quad$ Arrays of EAP micro-actuators for single-cell stretching applications [7642-14]

S. Akbari, M. Niklaus, H. Shea, Ecole Polytechnique Fédérale de Lausanne (Switzerland)

7642 Ol Artificial muscle actuators for haptic displays: system design to match the dynamics and tactile sensitivity of the human fingerpad [7642-15]

S. J. Biggs, R. N. Hitchcock, Artificial Muscle, Inc. (United States)

\section{DIELECTRIC EAP ACTUATORS I}

7642 0J Materials science on the nano-scale for improvements in actuation properties of dielectric elastomer actuators (Invited Paper) [7642-16]

G. Kofod, D. N. McCarthy, H. Stoyanov, M. Kollosche, S. Risse, H. Ragusch, D. Rychkov,

M. Dansachmüller, R. Waché, Univ. Potsdam (Germany)

7642 OK Challenges in the microfabrication of dielectric elastomer actuators [7642-17]

B. Balakrisnan, E. Smela, Univ. of Maryland, College Park (United States)

7642 OL Dielectric elastomer bending tube actuators with rigid electrode structures [7642-99] F. Wehrheim, Richard Wolf GmbH (Germany); H. F. Schlaak, Technische Univ. Darmstadt (Germany); J.-U. Meyer, Richard Wolf GmbH (Germany)

7642 OM Elastomer actuators: systematic improvement in properties by use of composite materials [7642-19]

M. Molberg, EMPA (Switzerland) and Ecole Polytechnique Fédérale de Lausanne (Switzerland); Y. Leterrier, C. J. G. Plummer, Ecole Polytechnique Fédérale de Lausanne (Switzerland); C. Löwe, D. M. Opris, F. Clemens, EMPA (Switzerland); J.-A. E. Månson, Ecole Polytechnique Fédérale de Lausanne (Switzerland)

\section{DIELECTRIC EAP ACTUATORS II}

7642 ON Experimental study on behaviors of dielectric elastomer based on acrylonitrile butadiene rubber [7642-20]

K. An, N. H. Chuc, H. Y. Kwon, V. H. Phuc, J. Koo, Y. Lee, J. Nam, H. R. Choi, Sungkyunkwan Univ. (Korea, Republic of)

$764200 \quad$ The dynamic properties of tubular DEAP actuators [7642-21] M. J. Tryson, R. Sarban, K. P. Lorenzen, Danfoss PolyPower A/S (Denmark)

7642 OP Radially expanding mechanism for dielectric elastomers [7642-22]

A. T. Conn, J. M. Rossiter, Univ. of Bristol (United Kingdom) 
7642 OR PDMS/graphite stretchable electrodes for dielectric elastomer actuators [7642-24]

M. Kujawski, J. Pearse, E. Smela, Univ. of Maryland, College Park (United States)

7642 OS Effects of conductive particles on the actuating behavior of dielectric elastomer actuator [7642-25]

Z. Zhang, Y. Liu, J. Leng, Harbin Institute of Technology (China)

7642 0T Thermodynamic model using experimental loss factors for dielectric elastomer actuators design [7642-26]

J-P. Lucking Bigué, P. Chouinard, M. Denninger, S. Proulx, J-S. Plante, Univ. de Sherbrooke (Canada)

IONIC EAP I

$76420 \mathrm{OU}$ IPMC: recent progress in modeling, manufacturing, and new applications (Invited Paper) [7642-27]

D. Pugal, Univ. of Nevada, Reno (United States) and Tartu Univ. (Estonia); S. J. Kim, K. J. Kim, K. K. Leang, Univ. of Nevada, Reno (United States)

7642 OV Experiments with self-sensing IPMC actuating device [7642-28]

K. Kruusamäe, Tartu Univ. (Estonia); P. Brunetto, S. Graziani, L. Fortuna, Univ. degli Studi di Catania (Italy); M. Kodu, R. Jaaniso, A. Punning, A. Aabloo, Tartu Univ. (Estonia)

7642 OW Conducting polymers as simultaneous sensor-actuators (Invited Paper) [7642-29]

T. Fernández-Otero, G. Vázquez, L. Valero, Univ. Politécnica de Cartagena (Spain)

7642 OX MEMS-based fabrication of multiple-degree-of-freedom ionic polymer-metal composite actuators [7642-30]

Z. Chen, X. Tan, Michigan State Univ. (United States)

7642 OY Effects of anisotropic surface texture on the performance of ionic polymer-metal composite (IPMC) [7642-31]

Q. He, M. YU, H. Ding, D. Guo, Z. Dai, Nanjing Univ. of Aeronautics and Astronautics (China)

$76420 Z$ Considerations for contractile electroactive materials and actuators [7642-32]

L. Rasmussen, D. Schramm, Ras Labs, LLC (United States); L. D. Meixler, C. A. Gentile,

G. Ascione, C. Tilson, K. Pagdon, Princeton Plasma Physics Lab. (United States)

\section{DIELECTRIC EAP ACTUATORS III}

764210 Asymptotically accurate non-linear analysis of electro-elastomer membrane structures [7642-33]

B. R. Gupta, D. Harursampath, S. Mukherjee, Indian Institute of Science Bangalore (India)

$764211 \quad$ Modeling approaches for electroactive polymers [7642-34]

W. Kaal, S. Herold, T. Melz, Fraunhofer Institute for Structural Durability and System Reliability (Germany) 
764212 Electrostriction in dielectric elastomer: effect on electromechanical actuation [7642-35] B. Li, Xi'an Jiaotong Univ. (China) and Harvard Univ. (United States); L. Liu, Harvard Univ. (United States) and Harbin Institute of Technology (China); J. Wu, Z. Zhu, H. Chen, Xi'an Jiaotong Univ. (China)

764213 Leakage current as a predictor of failure in dielectric elastomer actuators [7642-36]

T. A. Gisby, S. Q. Xie, The Univ. of Auckland (New Zealand); E. P. Calius, Industrial Research Ltd. (New Zealand); I. A. Anderson, The Univ. of Auckland (New Zealand)

764214 Modeling of non ideal dielectric elastomer stack actuators [7642-37]

P. Lotz, M. Matysek, K. Flittner, H. F. Schlaak, Technische Univ. Darmstadt (Germany)

764215 Dielectric elastomeric bimorphs using electrolessly deposited silver electrodes [7642-38]

S. C.-K. Goh, G.-K. Lau, Nanyang Technological Univ. (Singapore)

764216 An integrated dielectric elastomer generator model [7642-39]

T. McKay, B. O'Brien, The Univ. of Auckland (New Zealand); E. Calius, Industrial Research Ltd. (New Zealand); I. Anderson, The Univ. of Auckland (New Zealand)

764217 Energy harvesting cycles based on electro active polymers [7642-120]

C. Graf, J. Maas, Ostwestfalen-Lippe Univ. of Applied Sciences (Germany); D. Schapeler, Bayer MaterialScience AG (Germany)

\section{IONIC EAP II}

764219 Conductive filler morphology effect on performance of ionic polymer conductive network composite actuators [7642-42]

S. Liu, Y. Liu, The Pennsylvania State Univ. (United States); H. Cebeci, R. G. de Villoria, Massachusetts Institute of Technology (United States); J.-H. Lin, The Pennsylvania State Univ. (United States); B. L. Wardle, Massachusetts Institute of Technology (United States); Q. Zhang, The Pennsylvania State Univ. (United States)

$76421 \mathrm{~A}$ Transports of ionic liquids in ionic polymer conductor network composite actuators [7642-43]

Y. Liu, S. Liu, J. Lin, The Pennsylvania State Univ. (United States); D. Wang, V. Jain,

R. Montazami, J. R. Heflin, J. Li, L. Madsen, Virginia Polytechnic Institute (United States);

Q. M. Zhang, The Pennsylvania State Univ. (United States)

$76421 \mathrm{~B}$ Experimental investigations on carbon nanotube actuators defining the operation point and its standard deviation [7642-44]

U. Kosidlo, R. Addinall, F. Tonner, I. Kolaric, C. Glanz, Fraunhofer Institute for Manufacturing Engineering and Automation (Germany)

\section{OTHER TYPES OF EAP MATERIALS I}

7642 1D Ionic polymer metal composites with nanoporous carbon electrodes [7642-46]

V. Palmre, Tartu Univ. (Estonia); D. Brandell, Uppsala Univ. (Sweden); U. Mäeorg, J. Torop, Tartu Univ. (Estonia); O. Volobujeva, Tallinn Univ. of Technology (Estonia); A. Punning, U. Johanson, A. Aabloo, Tartu Univ. (Estonia) 
$76421 \mathrm{E}$ Dielectric elastomer actuators of silicone rubber-titanium dioxide composites obtained by dielectrophoretic assembly of filler particles [7642-47]

S. Javadi, M. Razzaghi-Kashani, Tarbiat Modares Univ. (Iran, Islamic Republic of)

$76421 G$ Self-assembled regular arrays of carbon nanotube and the route toward actuation of shape memory polymer [7642-49]

H. Lu, C. Wu, Y. Liu, Harbin Institute of Technology (China); J. Gou, Univ. of Central Florida

(United States); J. Leng, Harbin Institute of Technology (China)

$76421 \mathrm{H}$ Thermomechanical properties of multiwalled carbon nanotube reinforced shape-memory polymer nanocomposite [7642-50]

J. Zhong, G. Xian, L. Li, Harbin Institute of Technology (China)

764211 The constitutive relation of silicone rubber soft active materials [7642-51]

L. Liu, Harbin Institute of Technology (China) and Harvard Univ. (United States); S. Sun,

Z. Zhang, K. Yu, G. Yi, Y. Liu, J. Leng, Harbin Institute of Technology (China)

\section{MODELING AND ANALYSIS OF EAP}

$76421 \mathrm{~J} \mathrm{Multi-scale} \mathrm{mechanical} \mathrm{modelling} \mathrm{of} \mathrm{a} \mathrm{tubular} \mathrm{actuator} \mathrm{with} \mathrm{compliant} \mathrm{metal} \mathrm{electrodes}$ [7642-52]

P. Wang, B. Lassen, R. W. Jones, Univ. of Southern Denmark (Denmark)

7642 IL Nonlinear capacitance and electrochemical behavior of ionic liquid-ionic polymer transducers [7642-54]

J. D. Davidson, N. C. Goulbourne, Univ. of Michigan (United States)

$76421 \mathrm{~N}$ Thermo-chemo-electro-mechanical modeling of polyelectrolyte gels [7642-56]

T. Wallmersperger, K. Keller, B. Kröplin, Univ. Stuttgart (Germany); M. Günther, G. Gerlach,

Technische Univ. Dresden (Germany)

764210 Mechanical modeling of interpenetrating polymer network reinforced acrylic elastomer [7642-57]

A. Schmidt, A. Bergamini, G. Kovacs, EMPA (Switzerland); E. Mazza, ETH Zurich (Switzerland)

7642 1P Large deformations of reconfigurable active membranes: a finite element model [7642-58] S. Son, Virginia Polytechnic Institute and State Univ. (United States) and Univ. Of Michigan (United States); N. C. Goulbourne, Univ. of Michigan (United States)

IONIC EAP III

7642 is Optimization of bio-inspired multi-segment IPMC cilia [7642-61]

S. Sareh, A. T. Conn, J. M. Rossiter, Univ. of Bristol (United Kingdom) and Bristol Robotics Lab. (United Kingdom); I. leropoulos, P. Walters, Bristol Robotics Lab. (United Kingdom)

7642 IT Mechanical characterization of conducting polymer actuated neural probes under physiological settings [7642-62]

E. D. Daneshvar, Univ. of Michigan (United States); E. Smela, Univ. of Maryland, College Park (United States); D. R. Kipke, Univ. of Michigan (United States) 
$76421 \mathrm{R} \quad$ Robust PID force control of IPMC actuators [7642-63]

S. Sano, Toyohashi Univ. of Technology (Japan); K. Takagi, Nagoya Univ. (Japan) and RIKEN (Japan); S. Sato, S. Hirayama, N. Uchiyama, Toyohashi Univ. of Technology (Japan);

K. Asaka, AIST (Japan)

$76421 \mathrm{~V}$ Fabrication of multiwalled carbon nanotube polydimethylsiloxne nanocomposite polymer flexible microelectrodes for microfluidics and MEMS [7642-64]

A. Khosla, B. L. Gray, Simon Fraser Univ. (Canada)

7642 IW Design and implementation of dexterous robotic hand for human controlled interfaces: a comparative analysis with EAP systems [7642-88]

N. Thayer, S. Priya, Virginia Polytechnic Institute and State Univ. (United States)

\section{APPLICATION OF EAP I}

$76421 \mathrm{X}$ Dielectric electro active polymers: development of an industry (Invited Paper) [7642-66] M. Tryson, H-E. Kiil, Danfoss PolyPower A/S (Denmark)

7642 1Y A hybrid microbial dielectric elastomer generator for autonomous robots [7642-67] I. A. Anderson, The Univ. of Auckland (New Zealand); I. Ieropoulos, Bristol Robotics Lab. (United Kingdom); T. McKay, B. O'Brien, The Univ. of Auckland (New Zealand); C. Melhuish, Bristol Robotics Lab. (United Kingdom)

\section{CONTROL OF EAP ACTUATORS I}

764212 BISMAC control using SMA resistance feedback [7642-68]

A. Villanueva, S. Priya, Virginia Polytechnic Institute and State Univ. (United States)

764220 Biomimetic control for DEA arrays [7642-69]

B. O'Brien, T. Gisby, S. Q. Xie, The Univ. of Auckland (New Zealand); E. Calius, Industrial Research Ltd. (New Zealand); I. Anderson, The Univ. of Auckland (New Zealand)

$764221 \quad$ Sectored-electrode IPMC actuator for bending and twisting motion [7642-70] R. O. Riddle, Y. Jung, S.-M. Kim, S. Song, B. Stolpman, K. J. Kim, K. K. Leang, Univ. of Nevada, Reno (United States)

\section{APPLICATION OF EAP II}

764222 Synthesis and characterization of polypyrrole composite actuator for jellyfish unmanned undersea vehicle [7642-71]

Y. Tadesse, J. Brennan, C. Smith, T. E. Long, S. Priya, Virginia Polytechnic Institute and State Univ. (United States)

764223 Large planar dielectric elastomer actuators for fish-like propulsion of an airship (Invited Paper) [7642-72]

C. Jordi, EMPA (Switzerland) and ETH Zurich (Switzerland); S. Michel, C. Dürager, EMPA (Switzerland); A. Bormann, C. Gebhardt, Aeroix GmbH (Germany); G. Kovacs, EMPA (Switzerland) 
764224 Dielectric elastomer actuators with zero-energy fixity [7642-73]

J. Rossiter, Univ. of Bristol (United Kingdom); K. Takashima, T. Mukai, RIKEN (Japan)

764225 Jamming as an enabling technology for soft robotics [7642-74]

E. Steltz, A. Mozeika, J. Rembisz, N. Corson, iRobot Corp. (United States); H. M. Jaeger, The Univ. of Chicago (United States)

\section{OTHER TYPES OF EAP MATERIALS II}

$764227 \quad$ Hydrogel-based piezoresistive biochemical microsensors [7642-76]

M. Guenther, V. Schulz, G. Gerlach, Technische Univ. Dresden (Germany);

T. Wallmersperger, Univ. Stuttgart (Germany); F. Solzbacher, J. J. Magda, P. Tathireddy,

G. Lin, M. P. Orthner, The Univ. of Utah (United States)

764228 Flexible strain sensor for air muscles using polypyrrole coated rubber [7642-77]

A. P. Tjahyono, K. C. Aw, J. Travas-Sejdic, K. C. Li, The Univ. of Auckland (New Zealand)

7642 2A Electromechanical characteristics of actuators based on carbide-derived carbon [7642-79] J. Torop, F. Kaasik, Univ. of Tartu (Estonia); T. Sugino, National Institute of Advanced Industrial Science (Japan); A. Aabloo, Univ. of Tartu (Estonia); K. Asaka, National Institute of Advanced Industrial Science (Japan)

\section{CONTROL OF EAP ACTUATORS II}

7642 2C Nonlinear force control of dielectric electroactive polymer actuators [7642-81]

M. Y. Ozsecen, C. Mavroidis, Northeastern Univ. (United States)

7642 2D Closed loop control of a rotational joint driven by two antagonistic dielectric elastomer actuators [7642-82]

M. Randazzo, M. Fumagalli, G. Metta, G. Sandini, Italian Institute of Technology (Italy)

$76422 \mathrm{E} \quad$ Active vibration control using DEAP actuators [7642-83]

R. Sarban, Danfoss PolyPower A/S (Denmark); R. W. Jones, Univ. of Southern Denmark (Denmark)

7642 2G Flexible enhanced energy density composites for dielectric elastomer actuators [7642-85] H. Stoyanov, M. Kollosche, D. N. McCarthy, S. Risse, A. Becker, H. Ragusch, G. Kofod, Univ. of Potsdam (Germany)

\section{APPLICATION OF EAP III}

764221 Development of a deformable mirror based on conductive polymer actuator arrays for adaptive optics [7642-90]

A. D. Price, H. E. Naguib, F. Ben Amara, Univ. of Toronto (Canada)

7642 2J Factors influencing the performance of dielectric elastomer energy harvesters [7642-91]

P. Brochu, H. Li, X. Niu, Q. Pei, Univ. of California, Los Angeles (United States) 
7642 2K Array of lenses with individually tunable focal-length based on transparent ion-implanted EAPs [7642-92]

M. Niklaus, S. Rosset, H. Shea, Ecole Polytechnique Fédérale de Lausanne (Switzerland)

$76422 \mathrm{M} \quad$ Active skin as new haptic interface [7642-94]

N. H. L. Vuong, H. Y. Kwon, N. H. Chuc, D. Kim, K. An, V. H. Phuc, H. Moon, J. Koo, Y. Lee, J.-D. Nam, H. R. Choi, Sungkyunkwan Univ. (Korea, Republic of)

\section{POSTER SESSION}

$764220 \quad$ Novel cellulosic gel preparation for using in electro-responsive applications [7642-65] W. Kunchornsup, A. Sirivat, Chulalongkorn Univ. (Thailand)

7642 2P Electric field modelling of DEAP material with compliant metal electrodes [7642-96] P. Wang, R. W. Jones, B. Lassen, Univ. of Southern Denmark (Denmark)

$76422 \mathrm{Q} \quad$ Active vibration control of periodic disturbances using a DEAP damper [7642-97] R. Sarban, Danfoss PolyPower A/S (Denmark); R. W. Jones, Univ. of Southern Denmark (Denmark); B. Mace, E. Rustighi, Univ. of Southampton (United Kingdom)

$76422 \mathrm{U} \quad$ Electrically driven PEDOT/PSS actuators [7642-102]

H. Okuzaki, K. Hosaka, H. Suzuki, Univ. of Yamanashi (Japan); T. Ito, Takano Co. Ltd. (Japan)

$76422 \mathrm{~V}$ Effect of strain on the electrical conductivity of a styrene-butadiene rubber [7642-103] Y. H. Kim, J. Y. Lim, J. Jose, J. Y. Kim, G-B. Lee, Chonbuk National Univ. (Korea, Republic of); A. N. Gent, Chonbuk National Univ. (Korea, Republic of) and The Univ. of Akron (United States); C. Nah, Chonbuk National Univ. (Korea, Republic of)

7642 2W Integration of dielectric elastomer stack actuators into micro systems [7642-104] K. Flittner, M. Schlosser, P. Lotz, M. Matysek, H. F. Schlaak, Technische Univ. Darmstadt (Germany)

7642 2X Dependence on boundary conditions for actuation characteristics of dielectric elastomer actuators [7642-106]

M. Kollosche, H. Stoyanov, H. Ragusch, G. Kofod, Univ. Potsdam (Germany)

7642 2Y A novel approach to tunable diffractive transmission gratings based on dielectric elastomer actuators [7642-107]

M. Kollosche, Univ. of Potsdam (Germany); S. Döring, Fraunhofer-Institut für Angewandte Polymerforschung (Germany); G. Kofod, Univ. of Potsdam (Germany); J. Stumpe,

Fraunhofer-Institut für Angewandte Polymerforschung (Germany)

$76422 Z$ Modeling ionic polymer diluent response in sensing [7642-108]

U. T. Zangrilli, L. M. Weiland, Univ. of Pittsburgh (United States)

764231 Electro-mechanical properties of novel large strain PolyPower film and laminate components for DEAP actuator and sensor applications [7642-110]

M. Benslimane, H-E. Kiil, M. J. Tryson, Danfoss PolyPower A/S (Denmark) 
764233 Electromechanical properties of silicone-PZT (lead-zirconate-titanate) composite [7642-114]

N. Gharavi, M. Razzaghi Kashani, A. Moradi, Tarbiat Modares Univ. (Iran, Islamic Republic of)

764234 High-resolution tactile display operated by an integrated 'Smart Hydrogel' actuator array [7642-115]

G. Paschew, A. Richter, Technische Univ. Dresden (Germany)

764235 Utilization of electroactive polymer actuators in micromixing and in extended-life biosensor applications [7642-116]

V. Ho, M. Shimada, D. Szeto, Univ. of California, Irvine (United States); X. Casadevall i Solvas, Imperial College, London (United Kingdom); D. Scott, Univ. of Kentucky (United States); L. S. Dolci, Univ. degli Studi di Bologna (Italy); L. Kulinsky, Univ. of California, Irvine (United States); S. Daunert, Univ. of Kentucky (United States); M. Madou, Univ. of California, Irvine (United States)

764238 The area of allowable states in Mooney-Rivlin type dielectric elastomer generators [7642-119]

L. Liu, Harbin Institute of Technology (China) and Harvard Univ. (United States); S. Sun, K. YU, Harbin Institute of Technology (China); B. Li, Harvard Univ. (United States) and Xi'an Jiaotong Univ. (China); Y. Liu, J. Leng, Harbin Institute of Technology (China)

764239 Analysis on electric energy of EAP generator using Smartpice [7642-121] G. Kang, J. Lee, J. Kwon, J. Hur, Korea Advanced Institute of Science and Technology (Korea, Republic of); K. Cho, Agency for Defense Development (Korea, Republic of); K. Kim, S. Kim, Korea Advanced Institute of Science and Technology (Korea, Republic of)

Author Index 
Downloaded From: https://www.spiedigitallibrary.org/conference-proceedings-of-spie on 25 Apr 2023

Terms of Use: https://www.spiedigitallibrary.org/terms-of-use 


\title{
Conference Committee
}

\author{
Symposium Chairs
}

Donald J. Leo, Virginia Polytechnic Institute and State University (United States)

Kara J. Peters, North Carolina State University (United States)

Symposium Cochairs

Norbert G. Meyendorf, Fraunhofer-Institut für Zerstörungsfreie

Prüfverfahren (Germany)

Norman M. Wereley, University of Maryland, College Park

(United States)

Conference Chair

Yoseph Bar-Cohen, Jet Propulsion Laboratory (United States)

Conference Cochair

Jinsong Leng, Harbin Institute of Technology (China)

Program Committee

Barbar J. Akle, Lebanese American University (Lebanon)

Ray Henri Baughman, The University of Texas at Dallas (United States)

Václav Bouda, Czech Technical University in Prague (Czech Republic)

Emilio P. Calius, Industrial Research Ltd. (New Zealand)

Federico Carpi, Università di Pisa (Italy)

Toribio Fernandez-Otero, Universidad Politécnica de Cartagena

(Spain)

Edwin Jager, Linköpings Universitet (Sweden)

Keiichi Kaneto, Kyushu Institute of Technology (Japan)

Jaehwan Kim, Inha University (Korea, Republic of)

Kwang J. Kim, University of Nevada, Reno (United States)

Gabor K. Kovacs, EMPA (Switzerland)

Roy D. Kornbluh, SRI International (United States)

Maarja Kruusmaa, University of Tartu (Estonia)

Wen-Liang Liu, Industrial Technology Research Institute (Taiwan)

John David W. Madden, The University of British Columbia (Canada)

Jae-Do Nam, Sungkyunkwan University (Korea, Republic of)

Siavouche Nemat-Nasser, University of California, San Diego (United States)

Qibing Pei, University of California, Los Angeles (United States)

Subramaniam Radhakrishnan, National Chemical Laboratory (India) 
Mehdi Razzaghi-Kashani, Tarbiat Modarres University (Iran, Islamic Republic of)

Jonathan M. Rossiter, University of Bristol (United Kingdom)

Anuvat Sirivat, Chulalongkorn University (Thailand)

Peter Sommer-Larsen, Technical University of Denmark (Denmark)

Elisabeth Smela, University of Maryland, College Park (United States)

Ji Su, NASA Langley Research Center (United States)

Minoru Taya, University of Washington (United States)

Gordon G. Wallace, University of Wollongong (Australia)

Thomas Wallmersperger, Universität Stuttgart (Germany)

Gary Zaiats, Rafael Advanced Defense Systems Ltd. (Israel)

Qiming Zhang, The Pennsylvania State University (United States)

Session Chairs

1 EAP as Emerging Actuators and Biomimetic Technologies

Yoseph Bar-Cohen, Jet Propulsion Laboratory (United States)

Jinsong Leng, Harbin Institute of Technology (China)

2 Haptic/Tactile Interfaces and Braille Displays I

Qibing Pei, University of California, Los Angeles (United States)

Deane B. Blazie, National Braille Press (United States)

3 EAP-in-Action Session and Demonstrations

Yoseph Bar-Cohen, Jet Propulsion Laboratory (United States)

$4 \quad$ Haptic/Tactile Interfaces and Braille Displays II

Federico Carpi, Università di Pisa (Italy)

Noel H. Runyan, National Braille Press (United States)

5 Dielectric EAP Actuators I

Iain A. Anderson, The University of Auckland (New Zealand)

Hani E. Naguib, University of Toronto (Canada)

6 Dielectric EAP Actuators II

John Davd W. Madden, The University of British Columbia (Canada)

Guggi Kofod, Universität Potsdam (Germany)

7a Ionic EAP I

Hyouk Ryeol Choi, Sungkyunkwan University (Korea, Republic of)

Michael J. Tryson, Danfoss PolyPower A/S (United States)

7b Dielectric EAP Actuators III

Donald J. Leo, Virginia Polytechnic Institute and State University (United States)

Helmut F. Schlaak, Technische Universität Darmstadt (Germany) 
Ionic EAP II

Toribio Fernandez-Otero, Universidad Politécnica de Cartagena (Spain)

Jonathan M. Rossiter, University of Bristol (United Kingdom)

8b Other Types of EAP Materials I

Barbar J. Akle, Lebanese American University (Lebanon)

9a Modeling and Analysis of EAP

Thomas Wallmersperger, Universität Stuttgart (Germany)

Kwang J. Kim, University of Nevada, Reno (United States)

9b Ionic EAP III

Mircea Badescu, Jet Propulsion Laboratory (United States)

David Pugal, University of Nevada, Reno (United States)

10a Application of EAP I

Michael J. Tryson, Danfoss PolyPower A/S (United States)

Ja Choon Koo, Sungkyunkwan University (Korea, Republic of)

Thomas G. McKay, The University of Auckland (New Zealand)

10b Control of EAP Actuators I

Todd A. Gisby, The University of Auckland (New Zealand)

Bavani Balakrisnan, University of Maryland, College Park (United States)

$11 \mathrm{~b} \quad$ Other Types of EAP Materials II

Elisabeth Smela, University of Maryland, College Park (United States)

Bavani Balakrisnan, University of Maryland, College Park (United States)

12a Control of EAP Actuators II

Benjamin M. O'Brien, The University of Auckland (New Zealand)

Michael J. Tryson, Danfoss PolyPower A/S (United States)

12b Application of EAP III

Ravi Shankar, Intel Corporation (United States)

Thomas Wallmersperger, Universität Stuttgart (Germany) 
Downloaded From: https://www.spiedigitallibrary.org/conference-proceedings-of-spie on 25 Apr 2023

Terms of Use: https://www.spiedigitallibrary.org/terms-of-use 


\section{Introduction}

This SPIE's Electroactive Polymers Actuators and Devices (EAPAD) Conference is the leading international forum for presenting the latest progress and holding discussions among the attendees regarding the capabilities, challenges and potential future directions. The conference this year was co-chaired by Jinsong Leng, Harbin Institute of Technology (China) and included 120 presentations, which is the largest number of EAP-related papers that have ever been submitted. EAP materials are increasingly attracting researchers from many fields for their large displacement and functional similarity to biological muscles.

The Conference was well attended by leading world experts in the field including members of academia, industry, and government agencies from the USA and overseas. The Keynote speaker was Bharat Bhushan of The Ohio State Univ, and the title of his presentation was "Biomimetics: lessons from nature". In his presentation, he gave a broad overview of various objects and processes of interest found in nature and applications under development or available in the marketplace. He focused on the recent research on superhydrophobicity, selfcleaning, low adhesion/stiction, and highlighted drag reduction in fluid flow.

Turning EAP into actuators-of-choice requires solidifying the technical foundations and identifying niche applications taking advantage of their unique capabilities to provide edge for critical needs. Significant progress was reported in each of the topics of the EAP infrastructure. The papers focused on issues that can forge the transition to practical use, including improved materials, better understanding of the principles responsible for the electromechanical behavior, analytical modeling, processing and characterization methods, as well as considerations and demonstrations of various applications. Two special sessions were dedicated this year to the topic of haptic interfaces and refreshable Braille displays and they were chaired by Qibing Pei, Univ. of California, Los Angeles; Deane B. Blazie, National Braille Press as well as Federico Carpi, Univ. di Pisa (Italy); Noel H. Runyan, National Braille Press. Other topics that were covered in this conference included:

- Electroactive polymers (EAP) and non-electro active-polymer (NEAP) materials

- Theoretical models, analysis and simulation of EAP

- Methods of testing and characterization of EAP

- EAP as artificial muscles, actuators and sensors

- Design, control, intelligence, and kinematic issues related to robotic and biomimetic operation of EAP

- Under consideration and in progress applications of EAP 
The efforts described in the presented papers are showing significant improvements in understanding of the electromechanical principles and better methods of dealing with the challenges to the materials applications. Researchers are continuing to develop analytical tools and theoretical models to describe the electro-chemical and-mechanical processes, non-linear behavior as well as methodologies of design and control of the activated materials. EAP with improved response were described including dielectric elastomer, electrostrictive, IPMC, carbon nanotubes, conductive polymers, and other types. Specifically, there seems to be a significant trend in towards use of dielectric elastomers as practical EAP actuators.

This year, the EAP-in-Action Session was held on Monday, March 8, 2009 and it included eight demonstrations from Harbin Institute of Technology (China); Danfoss PolyPower A/S (Denmark); Univ. of Pisa, Research Centre "E. Piaggio" (Italy); The Auckland Bioengineering Institute's Biomimetics Lab. (New Zealand); Artificial Muscle, Inc. (AMI) (United States); National Braille Press (United States); Ras Labs. LLC (United States); Univ. of California, Los Angeles (United States); iRobot G\&I Research (United States).

To provide the attendees with opportunity to learn about EAP, an introductory course was given on Sunday, March 7, 2009 as part of the EAPAD Conference. The course was entitled "Electroactive Polymer Actuators and Devices," and the lead instructor was the Conf. Chair, Yoseph Bar-Cohen, who presented an overview, and covered applications that are currently developed and ones that are being considered. The subject of ionic EAP was covered by John D. W. Madden, the Univ. of British Columbia, Canada, while the topic of electronic EAP was covered by Qibing Pei from the University of California at Los Angeles (UCLA). For those who are seeking to self-learn about EAP, a comprehensive coverage of the topic is given in the $2^{\text {nd }}$ Edition of the book that was published by SPIE Press entitled "Electroactive Polymers (EAP) actuators as artificial muscles" [http://ndeaa.jpl.nasa.gov/nasa-nde/yosi/yosi-books.htm], as well as the WW-EAP webhub: [http://eap.jpl.nasa.gov] with links to the leading research and development labs worldwide, and the WW-EAP Newsletter.

In closing, we would like to extend a special thanks to all the conference attendees, session chairs, the EAP-in-Action demo presenters, the members of the EAPAD program organization committee. In addition, special thanks are extended to the SPIE staff that helped making this conference a great success.

Yoseph Bar-Cohen 